\title{
Botanical gardens as key resources and hazards for biosecurity
}

\author{
Mesfin Wondafrash ${ }^{1,2}$ - Michael J. Wingfield ${ }^{3}$ (D) John R. U. Wilson ${ }^{2,4}$ (D) \\ Brett P. Hurley ${ }^{1}$ (D) Bernard Slippers ${ }^{3}$ (D) Trudy Paap $^{3}$ (D)
}

Received: 13 February 2021 / Revised: 29 March 2021 / Accepted: 5 April 2021

(C) The Author(s), under exclusive licence to Springer Nature B.V. 2021

\begin{abstract}
Biodiversity and economic losses resulting from invasive plant pests and pathogens are increasing globally. For these impacts and threats to be managed effectively, appropriate methods of surveillance, detection and identification are required. Botanical gardens provide a unique opportunity for biosecurity as they accommodate diverse collections of exotic and native plant species. These gardens are also often located close to high-risk sites of accidental invasions such as ports and urban areas. This, coupled with routine activities such as the movement of plants and plant material, and visits by millions of people each year, place botanical gardens at risk to the arrival and establishment of pests and pathogens. Consequently, botanical gardens can pose substantial biosecurity risks to the environment, by acting as bridgeheads for pest and pathogen invasions. Here we review the role of botanical gardens in biosecurity on a global scale. The role of botanical gardens has changed over time. Initially, they were established as physic gardens (gardens with medicinal plants), and their links with academic institutions led to their crucial role in the accumulation and dissemination of botanical knowledge. During the second half of the 20th century, botanical gardens developed a strong focus on plant conservation, and in recent years there has been a growing acknowledgement of their value in biosecurity research as sentinel sites to identify pest and pathogen risks (novel pest-host associations); for early detection and eradication of pests and pathogens; and for host range studies. We identify eight specific biosecurity hazards associated with botanical gardens and note potential management interventions and the opportunities these provide for improving biosecurity. We highlight the value of botanical gardens for biosecurity and plant health research in general, and the need for strategic thinking, resources, and capacity development to make them models for best practices in plant health.
\end{abstract}

Keywords Invasive pests · Invasive pathogens $\cdot$ Early detection · Early warning $\cdot$ Sentinel plants $\cdot$ Invasive alien species

Communicated by David Hawksworth.

This article belongs to the Topical Collection: Ex situ conservation.

Mesfin Wondafrash

mesfin.gossa@fabi.up.ac.za

Extended author information available on the last page of the article 


\section{Introduction}

Invasive alien pests and pathogens pose major threats to plant health globally, resulting in significant ecological and economic damage (Holmes et al. 2009; Aukema et al. 2011; Boyd et al. 2013; Lovett et al. 2016). Huge economic losses in the agricultural and forestry sector have been attributed to the damage caused by invasive alien pests, for example up to $\$ 39$ billion per year in the United States alone (Pimentel et al. 2005; Holmes et al. 2009; Pratt et al. 2017). Over the last few decades, there has been a rapid surge in the number of alien arthropod pests, microbial pathogens and parasitic nematodes (hereafter referred to as pests) of plants in many countries (Aukema et al. 2010; Liebhold et al. 2012; Santini et al. 2013; Wingfield et al. 2015; Hurley et al. 2016). This recent surge is commonly attributed to the increasing global network of trade, travel and, in particular, the movement of live plants (Hulme 2009; Roques et al. 2009; Santini et al. 2013).

Regulatory measures that are taken against alien pests include the listing of quarantine pests [as supported by Pest Risk Analyses (PRAs)] and plant passports/quarantine inspections i.e. visual inspections/lab analyses (Klapwijk et al. 2016). However, such interventions are severely hampered by a lack of knowledge on potential pests and novel pest-host associations (Eschen et al. 2019). Co-evolution between plant pests and their hosts, as well as pressures from competition, predation and parasitism, contribute to the complexity and stability of natural ecosystems. Outbreaks of native pests under natural environmental conditions, are therefore rare (Alpert 2006; Burdon and Thrall 2009). Consequently, many damaging invasive alien plant pests were unknown to science, or at least unknown to cause severe damage, prior to their arrival and establishment in a novel environment. Examples include Dutch elm disease, Ophiostoma ulmi sensu lato (Ophiostomatales: Ophiostomataceae) and chestnut blight, Cryphonectria parasitica (Diaporthales: Cryphonectriaceae) in Europe and America (Brasier 2000; Rigling and Prospero 2018); and the polyphagous shot hole borer (PSHB), Euwallacea fornicatus (Coleoptera: Curculionidae) and its fungal symbiont Fusarium euwallaceae (Hypocreales: Nectriaceae) in California, Israel and South Africa (Mendel et al. 2012; Eskalen et al. 2013; Paap et al. 2018). Once established in a novel environment, these and many other pests have caused devastating economic and environmental impacts.

Early detection of pest incursions after their arrival is essential for control and management interventions to achieve eradication or containment, and for impacts and risks to be managed cost-effectively (Mehta et al. 2007; Liebhold and Kean 2019). In Australia, it has been estimated that their biosecurity system (by detecting and responding to introductions of pests and thereby reducing future impacts) will result in a net national benefit of AUS $\$ 314$ billion (an equivalent of US $\$ 210$ billion) over the next 50 years (Dodd et al. 2020). However, the detection of pests at the early stages of an incursion is challenging (Klapwijk et al. 2016; Thakur et al. 2019; Paap et al. 2020). Detection is often impossible before signs and symptoms develop on the host plants, and visible impacts are observed in the recipient environment (Thakur et al. 2019). By this point in time, the pest may already be well established. In addition, the diagnostic processes required to identify the organism(s) responsible for the damage further add to the long lag time between arrival, detection and identification of alien species. This is further exacerbated by the limited resources available to monitor large areas, particularly in countries with minimal budgets for plant health surveillance.

One strategy to improve the detection rate of incursions and identification of pest risks is to monitor sentinel plants i.e., plants already present in the vicinity of high-risk sites or 
in urban areas and used for regular inspection of pests (Britton et al. 2010; Eschen et al. 2019; Mansfield et al. 2019). A similar approach is to use sentinel plantings-plantings in the country of origin of the pests used to identify organisms in their native range that are likely to be harmful if introduced and establish elsewhere (Roques et al. 2015; Eschen et al. 2019). Sentinel plantings could be existing collections of plants in botanical gardens or plants planted for this purpose. Sentinel plants and sentinel plantings help to detect and identify pest risks effectively and are useful for early warning (Wylie et al. 2008; Sweeney et al. 2012; Paap et al., 2017; Morales-Rodríguez et al. 2019). An example of the potential role of sentinel plantings is the emerald ash borer, Agrilus planipennis (Coleoptera: Buprestidae), one of the devastating invasive insect pests in the United States (Herms and McCullough 2014). The emerald ash borer was detected on North American ash species planted in the beetle's native range in China long before its introduction in North America (Liu et al. 2003).

Botanical gardens provide a unique resource of sentinel plants and sentinel plantings to identify recently introduced alien pests and novel pest-host associations. There are thousands of botanical gardens widely distributed across the world with diverse collections of native and exotic plants (Miller et al. 2015; Barham et al. 2016). The high diversity of plant species in botanical gardens and their proximity to high-risk sites of introduction makes them suitable sites for post-border surveillance and monitoring of alien pests. Staff in these gardens work amongst the plant collections on a daily basis. Therefore, raising awareness and building the capacity of garden staff in surveillance and detection of pests can provide increased opportunities for detection of pests. This is especially useful for countries with limited plant health surveillance and biosecurity budgets. On the other hand, botanical gardens pose various biosecurity hazards through their regular activities such as collection, cultivation, sharing and the sale of plant materials; the use of machinery, vehicles and equipment; outsourcing of organic material; and tourism. These activities could lead to the introduction, establishment and spread of invasive species (Coetzee et al. 2001; Dawson et al. 2008; Scalera et al. 2012; Harrower et al. 2018; Rigling and Prospero 2018).

In this review we consider the changing role of botanical gardens, identify the associated hazards and highlight the recent recognition of their value for biosecurity. We discuss their potential role as bridgeheads and conduits of pest invasions, but also their recent role as key resources for identifying pest risks and new pest-host associations, as well as their potential to aid in pest detection and eradication.

\section{Changing attitudes to biosecurity in botanical gardens as their functions and roles evolve}

The functions and the roles of botanical gardens have evolved significantly over time (Powledge 2011; Krishnan and Novy 2016). Initially (mid-sixteenth century), botanical gardens were established to study medicinal plants (Oldfield 2007). However, during the European expansion and exploration of the rest of the world (seventeenth to nineteenth century), botanical gardens such as the Royal Botanic Gardens, Kew in Britain and the Hortus Botanicus Leiden in the Netherlands were engaged in economic botany and cultivation of attractive plants (Brockway 1979). This led to the movement of plants at unprecedented levels and enhanced the collection and documentation of exotic and previously unknown plant specimens (Brockway 1979; Borsch and Lohne 2014; Krishnan and Novy 2016). During the second half of the twentieth century, botanical gardens around the world 
developed a strong focus on the conservation of rare and threatened plant species and the sustainable use of biodiversity to mitigate the impacts of climate change, habitat loss, and many other factors (Maunder et al. 2000; Borsch and Lohne 2014). In the twenty-first century, the focus of botanical gardens has moved towards maintaining relevance to communities and meeting their needs, locally and globally. Along with their role in ex situ conservation of biodiversity, botanical gardens have increased their focus on impactful education, research, and ecological restoration (Krishnan and Novy 2016; Smith 2019). Furthermore, the expertise of botanical gardens is being used in in situ conservation of plant biodiversity and ecological restoration (Chen et al. 2009; Krishnan and Novy 2016; Chen and Sun 2018).

Despite the general evolving roles and functions of botanical gardens overtime, their role in relation to biosecurity issues has remained largely unappreciated until recently. During the early days of the establishment of botanical gardens (mid-sixteenth century), the concept of native and alien pests was not recognised. Yet, there was a significant level of economic exchange between Europe and the rest of the world, and the resultant exchange of goods could have enhanced the movement of pests (Walter 2012). Likewise, during the seventeenth to nineteenth century, biosecurity was not acknowledged nor considered important, despite the unprecedented level of movement of plants across the world for various purposes (Brockway 1979). It was only in 1878 that the first attempt to regulate the international movement of plants was made in response to the significant damage caused by the insect Grape Phylloxera, Phylloxera vastatrix (Hemiptera: Phylloxeridae) (now Daktulosphaira vitifolia), to the viticulture industry (Santini et al. 2018).

A growing awareness of the importance of biosecurity was observed among botanical gardens as their focus shifted from economic botany and they began to acknowledge their role in science and plant conservation. However, much of this focus was on plant invasions (Lowe et al. 2000; Heywood 2011; Hulme 2011; Sharrock et al. 2011), and little attention was given to the movement of harmful plant pests. In the United States, voluntary codes of conduct and ethics such as the 'Chapel Hill Challenge' and the 'St Louis Declaration' were launched for botanical gardens, arboreta and the horticultural industry in 1999 and 2002, respectively (Hulme 2011). These codes of conduct set recommendations for the removal of invasive plants from living collections and plant sales, and for the control of invasive plants in botanical gardens. They also set recommendations for undertaking risk assessments on new collections. As a result, botanical gardens had begun to take action to combat the risk of plant invasions associated with their conservation efforts. For example, the European Botanical Gardens Consortium established an initiative to identify potential invasive taxa from botanical collections in various gardens. The consortium also alerted collectors of a potential invasion threat posed by their plant collections. Botanical gardens in the United States have instituted similar initiatives for the identification of invasive horticultural species (Heywood 2011; Sharrock et al. 2011).

In the last two decades, scientists have recognised the role that botanical gardens can play in plant health and biosecurity and tried to align this role with the conservation role of gardens to minimise the introduction and spread of pests (Barham et al. 2016; Eschen et al. 2019). To this end, the International Plant Sentinel Network (IPSN) (https://www. plantsentinel.org/) was launched in 2013 with the aim of providing support and resources needed by botanical gardens and arboreta to conduct research on plant health (Barham et al. 2016). The IPSN is an initiative developed by Botanic Gardens Conservation International (BGCI), to facilitate collaboration among botanical gardens and arboreta, National Plant Protection Organizations (NPPOs) and plant health scientists. In this regard, botanical gardens such as the Royal Botanic Garden Edinburgh in the United Kingdom (UK) have taken 
important steps to reduce opportunities for pests to develop in their ex situ conservation collections. They have made substantial efforts to develop protocols for quarantine and horticultural practices, and expanded visitor engagement and public education on plant pests. They have also implemented precautionary approaches for plant distribution in order to minimise the introduction of pests into the gardens and to halt their subsequent dispersal (Hayden 2020). The Royal Botanic Gardens Kew in the UK and the Botanic Gardens Biosecurity Network and Botanic Gardens Surveillance Network in Australia have formed important links with government plant health departments to enhance biosecurity through inspection and structured plant pest surveillance (https://extensionaus.com.au/botanicgar densbiosecurity/structured-plant-pest-surveillance-by-botanic-gardens-staff/, https://www. kew.org/read-and-watch/behind-the-scenes-plant-quarantine-unit).

Recently, botanical gardens have been used as sentinel sites for the detection of introduced alien pests (Paap et al. 2017; Eschen et al. 2019). Botanical gardens can also be viewed as ex-patria sentinel plantings or sentinel plantations, as proposed by Eschen et al. (2019). In this case, woody plants native to the importing country, which are growing in botanical gardens in the exporting country, can be used to monitor and identify pest risks. The identification of native pest-exotic host associations in the exporting country could provide valuable information of potential future invasion risks to the country of origin of the host plant (Britton et al. 2010; Barham et al. 2016; Paap et al. 2017; Eschen et al. 2019; Morales-Rodríguez et al. 2019).

\section{The role of botanical gardens in biosecurity}

The key elements and features that lend botanical gardens special importance in biosecurity, particularly in the study, detection and management of pests, are illustrated in Fig. 1 and the accompanying Table 1. Eight specific hazards were identified and are discussed, noting that the threats also provide opportunities for improved management and communication. In this section, we highlight the hazards and the opportunities botanical gardens present as bridgeheads and conduits for invasions; sentinel sites for the detection and eradication of pest incursions; important resources for research (focussing on the opportunities they provide to identify new pest-host association and thereby determine pest host range); and great opportunities for meaningful public engagement on biosecurity issues.

\section{Botanical gardens as bridgeheads and conduits for invasions}

Despite their clear role in biodiversity conservation, botanical gardens have historically acted as conduits for the introduction of invasive plants. For example, of the 34 plants listed by the IUCN as among 100 of the worst invasive species worldwide (Lowe et al. 2000), there is published evidence implicating botanical gardens as the most probable source of introduction for over half of these species (Hulme 2011).

There is no doubt that ex situ plant conservation plays a vital role in the conservation of plants, but it also poses high risk of pest introduction (Liebhold et al. 2012). Therefore, botanical gardens can also serve as pathways of introduction for invasive pests. It is possible for alien pests established in botanical gardens to spread further into the surrounding environment through various garden activities. Examples include invasion by chestnut blight, C. parasitica in the United States (Rigling and Prospero 2018) and the root rot fungus, Armillaria mellea (Agaricales: Physalacriaceae) in South Africa (Coetzee et al. 2001, 


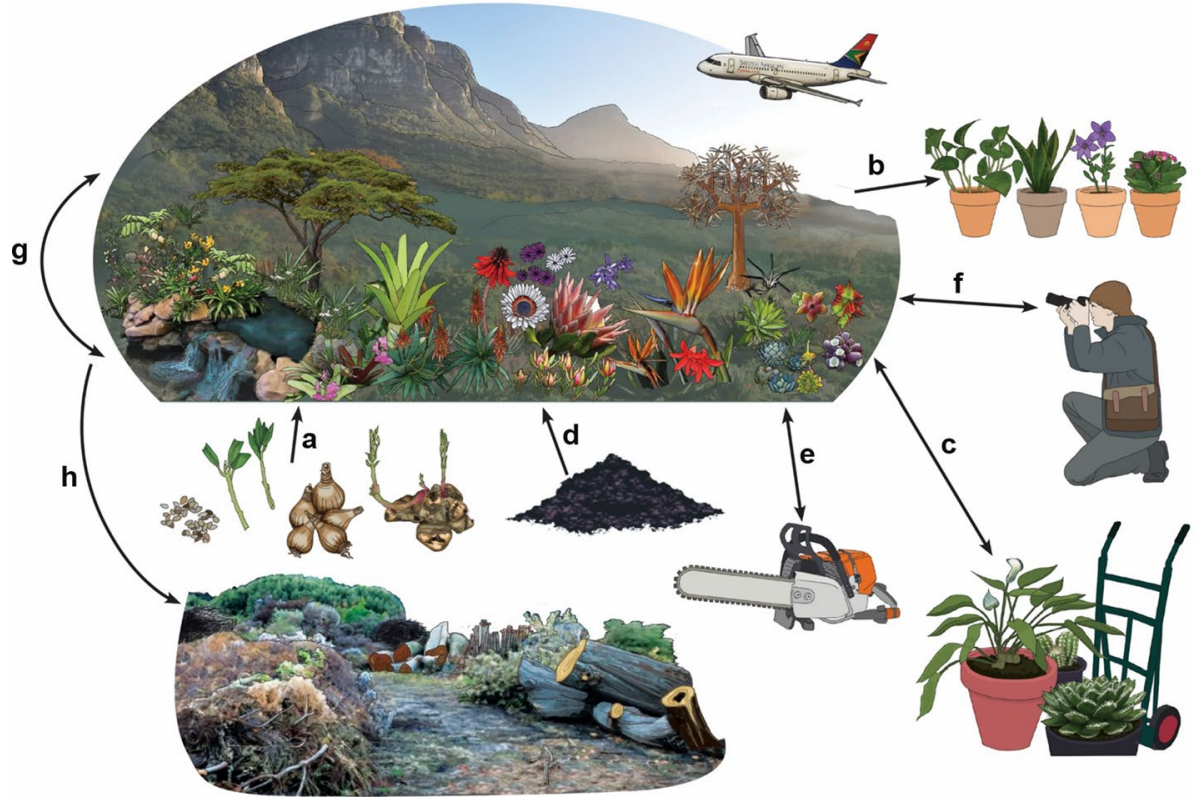

Fig. 1 Eight biosecurity hazards presented by botanical gardens and the opportunities they provide to improve management and communication. Details on the hazards, pathways of movement, real-world examples, management measures, and the corresponding opportunities are outlined in Table 1. The letters in the figures correspond to the letters in the table. The high diversity of native and exotic plant species in the gardens and their proximity to high risk sites such as ports and urban areas provides a unique opportunity for the detection and identification of pest risks. Materials going into the gardens such as seeds, tubers, cuttings, mulch, compost and soil could potentially transport and introduce pests to the gardens (a, d). On the other hand, materials leaving the gardens such as sold plants, prunings and dead plants can potentially transport pests established in the gardens to the external environment $(\mathbf{b}, \mathbf{h})$. Other activities of the gardens, including visits by local and international visitors (f), the use of machinery and equipment (e), and plant exchange between botanical gardens (c) may also serve as pathways of movement of pests to- and from the gardens. Additionally, pests may naturally disperse between managed estates of the gardens and the adjacent natural vegetation $(\mathbf{g})$

2003). In the United Sates, the first report of C. parasitica was on American chestnut in the Zoological Park of New York City in 1904 (Rigling and Prospero 2018). Subsequently, this pathogen spread to the surrounding environment and devastated native American chestnut trees. Similarly, A. mellea was initially detected in Company's Garden and Kirstenbosch National Botanical Garden in South Africa (Coetzee et al. 2001, 2003). It has recently been reported from the surrounding natural vegetation of Table Mountain National Park, a declared UNESCO world heritage site (Coetzee et al. 2018).

Plant donation from the Kirstenbosch National Botanical Garden in South Africa resulted in the accidental introduction of five sap-sucking hemipteran pests to London, the UK (Salisbury et al. 2011). Several pot-grown Aloe species together with a Cheiridopsis glomerata (Cryophyllales: Aizoaceae) were sent to London for the 2011 Royal Horticultural Society Chelsea Flower Show. At the end of the show, the plants were donated to the Royal Society of Chelsea. No pests were found on the plants despite assessments being made before and after the show. The donated plants were placed in the propagation department's quarantine facility. Within a month, it was clear that the plants were infested with several sap-sucking insects, which were later identified as five different insect species. Two 


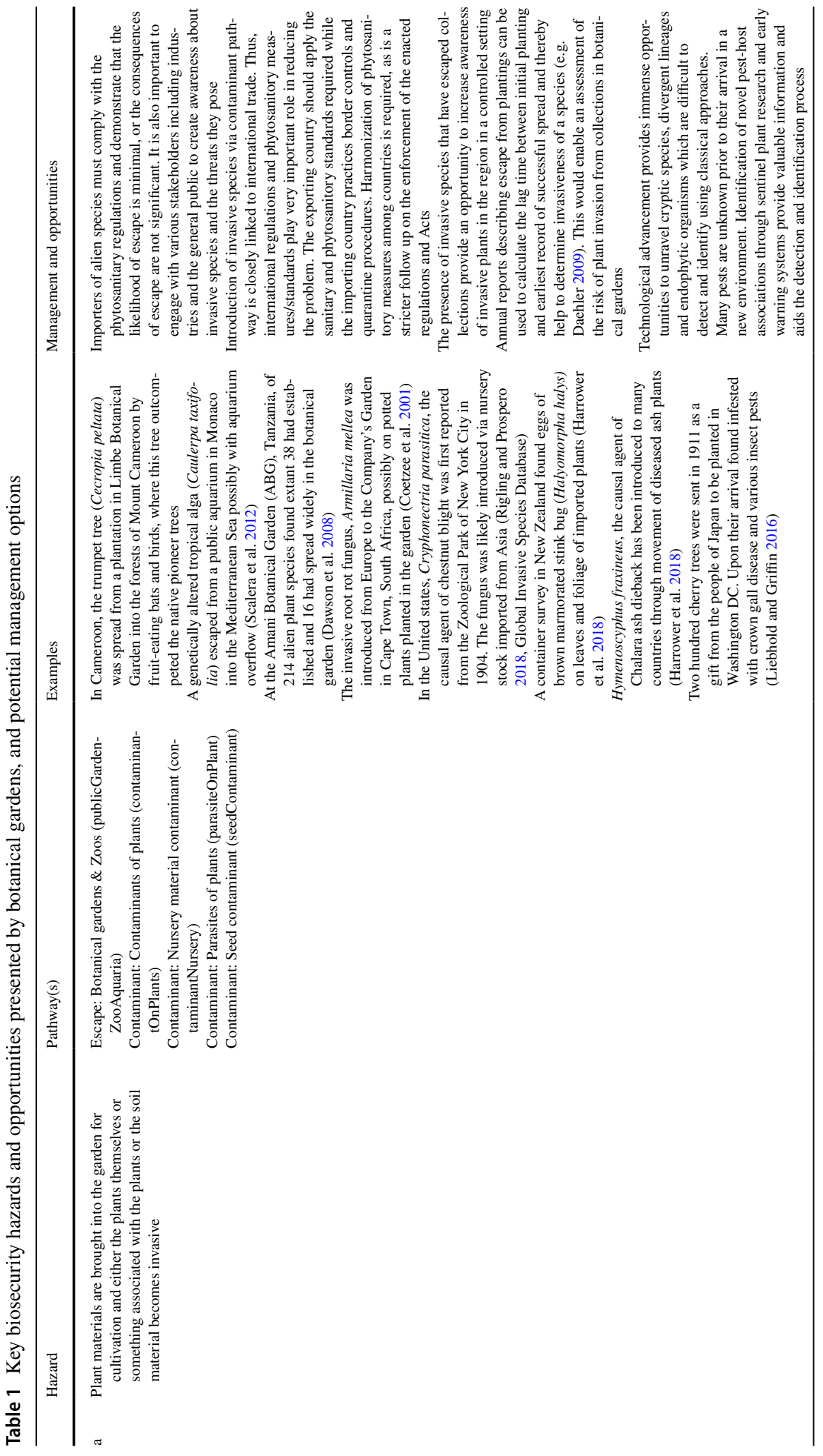




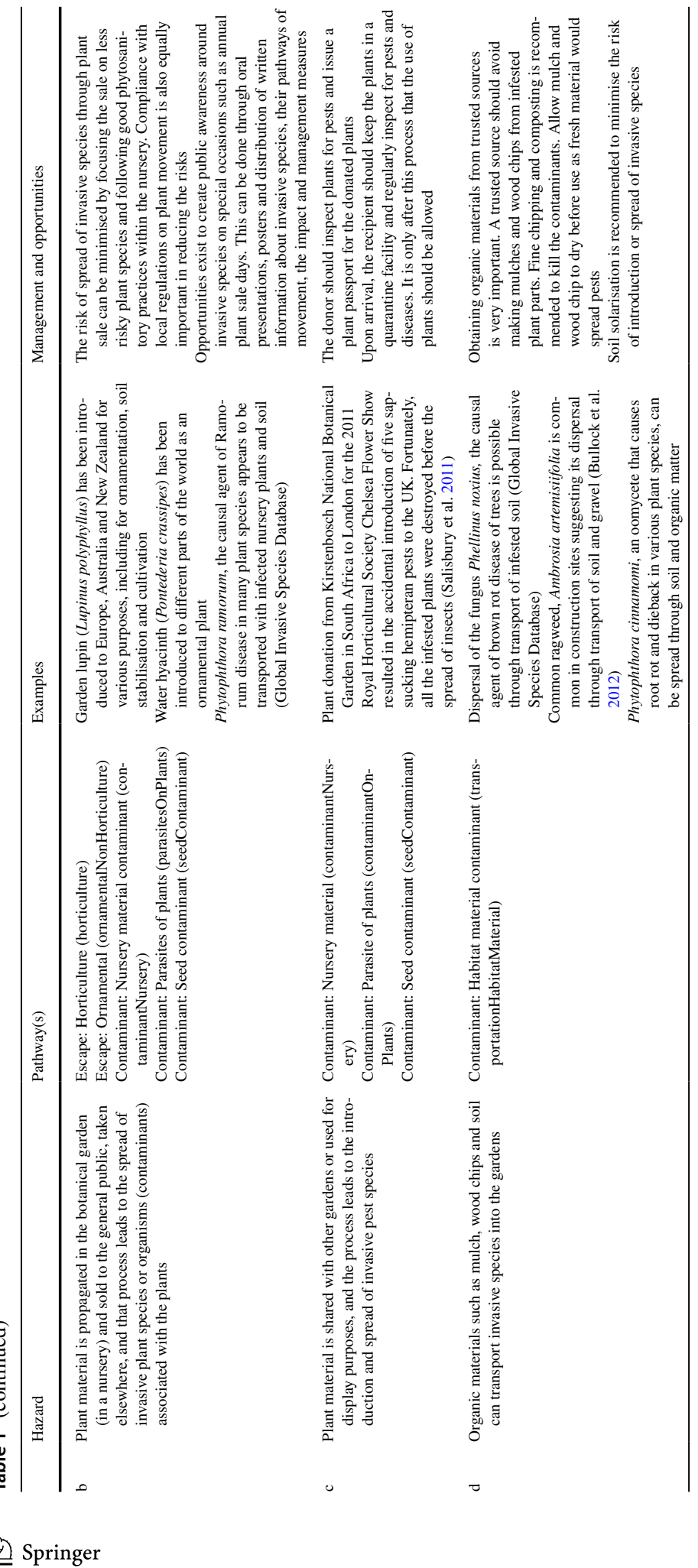




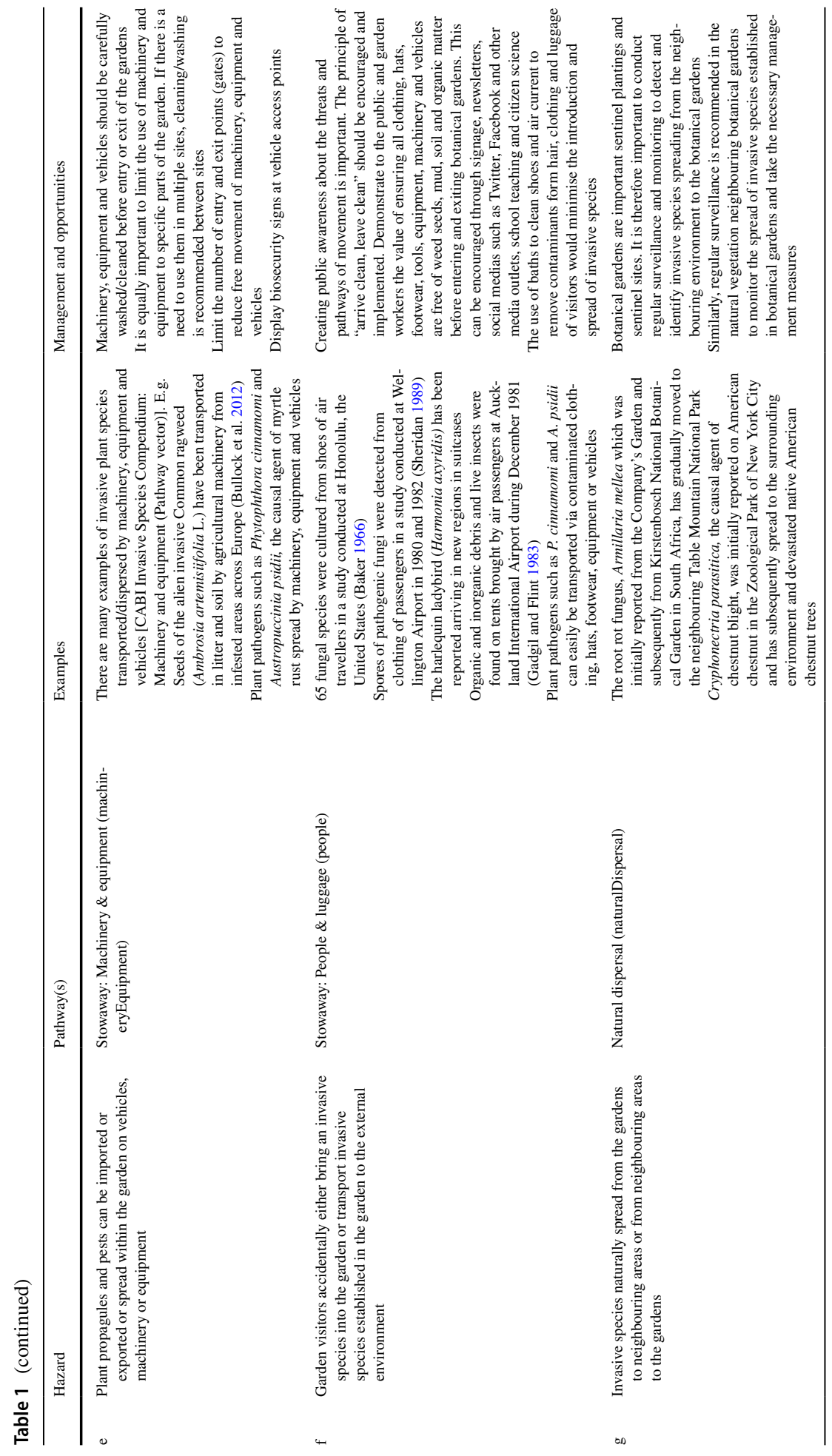




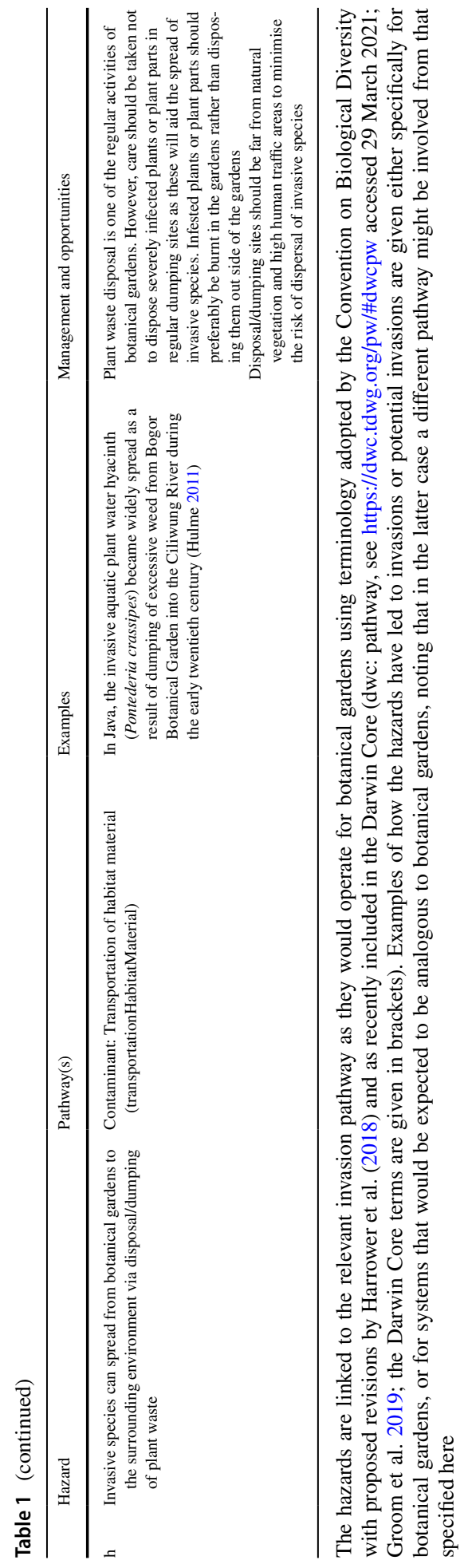


of these species, the small mirid bug, Aloea australis (Hemiptera: Myridae) and the iceplant scale, Pulvinaria delottoi (Hemiptera: Coccidae), were the first detections of these pests in Europe. Dried specimens of these pests were deposited in different insect reference collections and all the infested plants were destroyed. These examples demonstrate the need for quarantine and repeated inspections as during initial inspections, pests may have been at their immature stages and less visible.

\section{Botanical gardens as sentinel sites for the detection and eradication of pest incursions}

A recent move towards sentinel plant research has facilitated the detection and identification of emerging pest risks. Initiatives such the IPSN, COST Action Global Warning (https://www.cost.eu/actions/FP1401/\#tabs/Name:overview), and the European Union Horizon 2020 HOMED (Holistic Management of Emerging Forest Pests and Diseases) project (http://homed-project.eu/), are coordinating sentinel plant research globally. These projects serve to highlight the many first reports of pests from botanical gardens and arboreta (Jock et al. 2000; Salisbury et al. 2011; Paap et al. 2018; Hulbert et al. 2019; Tchotet Tchoumi et al. 2019). In South Africa alone, 67 pest species (including fungi, oomycetes, insects and mites) were detected and identified from various botanical gardens over the past 23 years (1996-2019), 20 of which were first reports for the country (Wondafrash et al. in prep). In a recent review article, Mansfield et al. (2019) reported several cases of novel pest-host associations identified from sentinel plants, including plants grown in botanical gardens. These novel associations involved insects, fungi, bacteria and nematodes. Timely detection and identification of such pests aids eradication and containment of new incursions, thereby reducing the risks to natural vegetation and commercial and agricultural systems (Jock et al. 2000; Kenis et al. 2019).

Globally, thousands of eradication programmes have been implemented for alien forest insects since 1970. These include many cases of successes and failures (Liebhold and Kean 2019). Historical examples of eradication include many successful localised gypsy moth, Lymantria dispar (Lepidoptera: Erebidae) eradication programs in the United States and the Asian long-horn beetle, Anoplophora glabripennis from Chicago, the United States; Toronto, Canada; and Braunau, Austria (Liebhold and Kean 2019). Recently (April 2020), E. fornicatus was detected on plants growing in a greenhouse in the botanical gardens of Trauttmansdorff Castle in Italy and eradication is underway (https://gd.eppo.int/reporting/ article-6772).

Eradication of plant pathogens once established in natural ecosystems presents a huge challenge (Paap et al. 2020). Yet, there are numerous examples of successful eradication of alien plant pathogens from controlled environments (Pluess et al. 2012). For example, inspection of known host plants of fire blight caused by the bacterium Erwinia amylovora (Enterobacterales: Erwiniaceae) in botanical gardens of Melbourne and Adelaide in Australia, resulted in its early detection in Royal Botanic Gardens, Melbourne (Jock et al. 2000). This is a pathogen endemic to North America and a causal agent of a serious disease of apple and pear trees and other rosaceous plants. Wide-ranging surveys and an intense host eradication program resulted in the removal of hundreds of trees, and protected Australia's pome fruit industry (Rodoni et al. 2002), valued at US\$560 million for the year 2014-15 (https://apal.org.au/). This demonstrates that the early recognition of new disease symptoms, coupled with rapid and accurate diagnostics, can lead to the successful 
eradication of damaging organisms. Early detection and identification of pests is more easily achieved in botanical gardens than other sites.

\section{Botanical gardens provide opportunities to determine pest host range}

The diverse collection of exotic and native plant species in botanical gardens are valuable resources to investigate and determine host ranges of pests (Groenteman et al. 2015; ScottBrown et al. 2018). Host range studies are not only valuable to the invaded region. Where exotic hosts are present, these studies can also inform other countries regarding possible future threats to their plant health, by contributing information on pests that are of regulatory interest (based on observed susceptibility in invaded ranges). These observations can be useful for early warning as they inform PRAs and assist with categorisation (quarantine status) of pests. Three examples of host range studies conducted in botanical gardens are presented below.

\section{Example 1. Euwallacea fornicatus-F. euwallaceae complex}

The host range of E. fornicatus and its fungal symbiont, F. euwallaceae, was studied at the Los Angeles Arboretum and the Huntington Botanical Gardens in its invasive range in California (Eskalen et al. 2013). Of the 335 tree species present in the gardens, 207 species (62\%), from 58 plant families, showed signs and symptoms of E. fornicatus infestation. Fusarium euwallaceae was isolated from $54 \%$ of the E. fornicatus infested plant species. Trees infested by E. fornicatus and its fungal symbiont included native and agriculturally important species, and common street trees. This study showed the potential of the beetle and its fungal symbiont to establish in diverse plant communities in the United States and beyond. The techniques used in this study and the results have aided the study of the beetle and its fungal symbiont in its recent introduced range in South Africa.

\section{Example 2. Xylella fastidiosa (Xanthomonadales: Xanthomonadaceae)}

This is a xylem-dwelling bacterium known to cause disease in a variety of plant species. The symptoms range from leaf scorch, chlorosis or browning to stunted growth, branch dieback and death of infected plants (CABI 2020). It is vectored by the glassy-winged sharpshooter (GWSS), Homalodisca vitripennis (Hemiptera: Cicadellidae). The combination of the vector and the bacterium causes severe damage in plants of agricultural, ornamental and biodiversity importance (Pilkington et al. 2005). The host range of X. fastidiosa and its vector GWSS and the biocontrol potential of egg parasitoids against GWSS was studied on New Zealand plants in four botanical gardens and arboreta and public spaces in southern California (Groenteman et al. 2015). Signs of GWSS activity were observed on 26 of the 102 plants (25\%) examined, while the bacterium was recovered at all the locations sampled and in $51 \%$ of the samples. This showed that several of New Zealand's indigenous plant species are susceptible to the bacterium.

\section{Example 3. Red palm mite, Raoiella indica (Trombidiformes: Tenuipalpidae)}

Since its detection in Martinique and St. Lucia in 2004, this polyphagous mite species has spread rapidly through the Neotropical region and has caused significant damage to a diverse range of plant species (Carrillo et al. 2012). The host range of $R$. indica was 
investigated through periodic surveys in the Fairchild Tropical Botanic Garden in Florida, the United States and the Royal Botanic Gardens of Trinidad and Tobago. This has helped to produce an updated list of 91 reproductive host species of $R$. indica. This study also confirmed 27 new reproductive hosts, representing a $30 \%$ increase of the previously recorded host range (Carrillo et al. 2012).

\section{Public engagement in botanical gardens}

Opportunities exist for public engagement in plant protection via the gardens, leading to citizen science and better understanding of threats posed by pests, their pathways of movement and biosecurity measures. Botanical gardens are visited by many people on a daily basis. Biosecurity teams of the botanical gardens can use this opportunity to create awareness regarding pest and pathogen risks, pathways of movement and the recommended measures as per operational biosecurity guidelines. This could be achieved in various ways, including presentations, practical demonstrations of pests and pathogens in the gardens, group discussions and by posting biosecurity signage (see Hayden 2020).

\section{Conclusions}

Botanical gardens pose a variety of biosecurity threats- here we characterised eight specific threats (Fig. 1, Table 1). However, botanical gardens also provide great opportunities to study invasive pests, invasive plants and native pests that damage exotic plants. Botanical gardens are important sentinel sites for the detection and discovery of pest species, and are valuable resources for host range studies and the identification of novel pest-host associations. We believe some botanical gardens are already champions of biosecurity, and argue that others can expand their role from sentinel sites for biosecurity research to become models for best practices in plant heath, in the global effort to limit the spread and impact of pests. This will require strategic thinking, resources, and capacity development. Yet, we strongly believe that such an approach would increase the value of the botanical gardens and the contribution that they make to biosecurity. Ex situ conservation is central to the role of many botanical gardens because of the increasing impacts of climate change, habitat loss, fragmentation, degradation, pollution and over-exploitation on plant biodiversity. This conservation role of botanical gardens needs to be aligned with biosecurity efforts in order to minimize the introduction of invasive pests to the gardens, and thus to halt their subsequent spread to the surrounding environment.

Acknowledgements The South African Department of Forestry, Fisheries and the Environment (DFFE) are thanked for funding noting that this publication does not necessarily represent the views or opinions of DFFE or its employees. The Forestry and Agricultural Biotechnology Institute (FABI) of the University of Pretoria is acknowledged for its infrastructural support. The horticulturalists at the various botanical gardens in South Africa deserve special thanks for their unreserved support on the project.

Authors contribution Conceptualization [TP, JRUW, MW], Formal analysis and investigation [TP, MW], Writing-original draft preparation [MW], Commenting the various versions of the manuscript and approval of the final version [MJW, JRUW, BPH, BS, TP].

Funding This work was supported by the South African Department of Forestry, Fisheries and the Environment (DFFE). 
Availability of data and material Data sharing is not applicable to this article as no datasets were generated or analysed during the current study.

\section{Declarations}

Conflict of interest The authors have no conflict of interest to declare that are relevant of the content of this article.

Consent for publication All the authors have given their consent for the submission and publication of this article.

\section{References}

Alpert P (2006) The advantages and disadvantages of being introduced. Biol Invasions 8:1523-1534. https://doi.org/10.1007/s10530-005-5844-z

Aukema JE, McCullough DG, Von Holle B, Liebhold AM, Britton K, Frankel SJ (2010) Historical accumulation of nonindigenous forest pests in the continental United States. Bioscience 60:886-897. https:// doi.org/10.1525/bio.2010.60.11.5

Aukema JE, Leung B, Kovacs K, Chivers C, Britton KO, Englin J, Frankel SJ, Haight RG, Holmes TP, Liebhold AM (2011) Economic impacts of non-native forest insects in the continental United States. PLoS ONE 6:e24587. https://doi.org/10.1371/journal.pone.0024587

Baker EG (1966) Inadvertent distribution of fungi. Can J Microbiol 12(109):112. https://doi.org/10.1139/ m66-016

Barham E, Sharrock S, Lane C, Baker R (2016) The International Plant Sentinel Network: a tool for Regional and National Plant Protection Organizations. Bulletin OEPP/EPPO Bulletin 46:156-162

Borsch T, Löhne C (2014) Botanic gardens for the future. Integrating research, conservation, environmental education and public recreation. Ethiop J Biol Sci 13:115-133

Boyd IL, Freer-Smith PH, Gilligan CA, Godfray HCJ (2013) The consequence of tree pests and diseases for ecosystem services. Science 342:1235773

Brasier CM (2000) Intercontinental spread and continuing evolution of the Dutch elm disease pathogens. In: Dunne CP (ed) The elms: breeding, conservation and disease management. Kluwer Academic Publishers, Boston, pp 61-72

Britton K, White P, Kramer A, Hudler G (2010) A new approach to stopping the spread of invasive insects and pathogens: early detection and rapid response via a global network of sentinel plantings. N Z J Sci 40:109-114

Brockway LH (1979) Science and colonial expansion: the role of the British Royal Botanic Gardens. Academic Press, New York

Bullock J, Beale S, Chapman D, Schafer S, Roy D, Girardello M, Haynes T, Beal S, Wheeler B, Dickie I, Phang Z, Tinch R, Čivić K, Delbaere B, Jones-Walters L, Hilbert A, Schrauwen A, Prank M, Sofiev M, Niemelä S, Räisänen P, Lees B, Skinner M, Finch S, Brough C (2012) Assessing and controlling the spread and the effects of common ragweed in Europe (ENV.B.2/ETU/2010/0037). European Commission, Final report

Burdon JJ, Thrall PH (2009) Coevolution of plants and their pathogens in natural habitats. Science 324:755756. https://doi.org/10.1126/science.1171663

CABI (2020) Xylella fastidiosa (Pierce's disease of grapevines). Invasive Species Compendium. https:// www.cabi.org/isc/datasheet/57195. Accessed 20 Aug 2020

Carrillo D, Amalin D, Hosein F, Roda A, Peña JE (2012) Host plant range of Raoiella indica (Acari: Tenuipalpidae) in areas of invasion of the New World. Exp Appl Acarol 57:271-289. https://doi.org/10. 1007/s 10493-011-9487-8

Carter PCS (1989) Risk assessment and pest detection surveys for exotic pests and diseases which threaten commercial forestry in New Zealand. N Z J For Sci 19:353-374

Chen G, Sun W (2018) The role of botanic gardens in scientific research, conservation, and citizen science. Plant Divers 40:181-188. https://doi.org/10.1016/j.pld.2018.07.006

Chen J, Cannon CH, Hu H (2009) Tropical botanical gardens: at the in situ ecosystem management frontier. Trends Plant Sci 14:584-589. https://doi.org/10.1016/j.tplants.2009.08.010 
Coetzee MPA, Wingfield BD, Harrington TC, Steimel J, Coutinho TA, Wingfiled MJ (2001) The root rot fungus Armillaria mellea introduced into South Africa by early Dutch settlers. Mol Ecol 10:387396. https://doi.org/10.1046/j.1365-294X.2001.01187.x

Coetzee MPA, Wingfield BD, Roux J, Crous JPW, Denman S, Wingfield MJ (2003) Discovery of two northern hemisphere Armillaria species on Proteaceae in South Africa. Plant Pathol 52:604-612. https://doi.org/10.1046/j.1365-3059.2003.00879.x

Coetzee MPA, Musasira NY, Roux J, Roets F, van der Merwe NA, Wingfield MJ (2018) Armillaria root rot spreading into a natural woody ecosystem in South Africa. Plant Pathol 67:883-891. https://doi. org/10.1111/ppa.12804

Daehler CC (2009) Short lag times for invasive tropical plants: evidence from experimental plantings in Hawai'i. PLoS ONE 4:e4462. https://doi.org/10.1371/journal.pone.0004462

Dawson W, Mndolwa AS, Burslem D, Hulme PE (2008) Assessing the risks of plant invasions arising from collections in tropical botanical gardens. Biodivers Conserv 17:1979-1995. https://doi.org/10. 1007/s10531-008-9345-0

Dodd A, Stoeckl N, Baumgartner J, Kompas T (2020) Key result summary: Valuing Australia's biosecurity system. Centre of Excellence for Biosecurity Risk Analysis (CEBRA) Report

Eschen R, Hanlon RO, Santini A, Vannini A, Roques A, Kirichenko N, Kenis M (2019) Safeguarding global plant health: the rise of sentinels. J Pest Sci 92:29-36. https://doi.org/10.1007/ s10340-018-1041-6

Eskalen A, Stouthamer R, Lynch SC, Twizeyimana M, Gonzalez A, Thibault T (2013) Host range of Fusarium dieback and its ambrosia beetle (Coleoptera: Scolytinae) vector in southern California. Plant Dis 97: 938-951

Gadgil PD, Flint TN (1983) Assessment of the risk of introduction of exotic forest insects and diseases with imported tents. N Z J For 28:58-67

Global Invasive Species Database. http://www.iucngisd.org/gisd/. Accessed 15 Nov 2020

Groenteman R, Forgie SA, Hoddle MS, Ward DF, Goeke DF, Anand N (2015) Assessing invasion threats: novel insect-pathogen-natural enemy associations with native New Zealand plants in southern California. Biol Invas 17:1299-1305. https://doi.org/10.1007/s10530-014-0804-0

Groom Q, Desmet P, Reyserhove L, Adriaens T, Oldoni D, Vanderhoeven S, Baskauf SJ, Chapman A, McGeoch M, Walls R, Wieczorek J, Wilson JRU, Zermoglio PFF, Simpson A (2019) Improving Darwin Core for research and management of alien species. Biodivers Inf Sci Stand 3:e38084. https://doi.org/10.3897/biss.3.38084

Harrower CA, Scalera R, Pagad S, Schönrogge K, Roy HE (2018) Guidance for interpretation of CBD categories on introduction pathways. Technical note prepared by IUCN for the European Commission

Hayden K (2020) Botanic gardens and plant pathogens: a risk-based approach at the Royal Botanic Garden Edinburgh. Sibbaldia. Int J Bot Garden Hortic 18:127-139. https://doi.org/10.24823/Sibbaldia. 2020.293

Herms DA, McCullough DG (2014) Emerald ash borer invasion of North America: history, biology, ecology, impacts, and management. Annu Rev Entomol 59:13-30. https://doi.org/10.1146/annur ev-ento-011613-162051

Heywood VH (2011) The role of botanic gardens as resource and introduction centres in the face of global change. Biodivers Conserv 20:221-239. https://doi.org/10.1007/.s10531-010-9781-5

Holmes T, Aukema J, Von Holl B, Liebhold A, Sills E (2009) Economic impacts of invasive species in forests. Ann NY Acad Sci 1162:18-38

Hulbert JM, Paap T, Burgess TI, Roets F, Wingfield MJ (2019) Botanical gardens provide valuable baseline Phytophthora diversity data. Urban For and Urban Gree 46:126461. https://doi.org/10.1016/j. ufug.2019.126461

Hulme PE (2009) Trade, transport and trouble: managing invasive species pathways in an era of globalization. J Appl Ecol 46:10-18. https://doi.org/10.1111/j.1365-2664.2008.01600.x

Hulme PE (2011) Addressing the threat to biodiversity from botanic gardens. Trends Ecol Evol 26:168174. https://doi.org/10.1016/j.tree.2011.01.005

Hurley BP, Garnas J, Wingfield MJ, Branco M, Richardson DM, Slippers B (2016) Increasing numbers and intercontinental spread of invasive insects on eucalypts. Biol Invas 18:921-933. https://doi.org/ 10.1007/s10530-016-1081-x

Jock S, Rodoni B, Gillings M, Kim WS, Copes C, Merriman P, Geider K (2000) Screening of ornamental plants from the Botanic Gardens of Melbourne and Adelaide for the occurrence of Erwinia amylovora. Australas Plant Path 29:120-128. https://doi.org/10.1071/AP00020

Kenis M, Hurley BP, Colombari F, Lawson S, Sun J, Wilcken C, Weeks R, Sathyapala S (2019) Guide to the classical biological control of insect pests in planted and natural forests. FAO Forestry Paper No. 182, Rome 
Klapwijk MJ, Hopkins AJM, Eriksson L, Pettersson M, Schroeder M, Lindelow A, Ronnberg J, Keskitalo $\mathrm{ECH}$, Kenis M (2016) Reducing the risk of invasive forest pests and pathogens: Combining legislation, targeted management and public awareness. Ambio 45:223-234. https://doi.org/10.1579/0044-744738.3.135

Krishnan S, Novy A (2016) The role of botanic gardens in the twenty-first century. CAB Reviews 11, No. 023

Liebhold AM, Griffin RL (2016) The legacy of Charles Marlatt and efforts to limit plant pest invasions. Am Entomol 62:218-227. https://doi.org/10.1093/ae/tmw072

Liebhold AM, Kean JM (2019) Eradication and containment of non-native forest insects: successes and failures. J Pest Sci 92:83-91. https://doi.org/10.1007/s10340-018-1056-Z

Liebhold A, Brockerhoff E, Garrett L, Parke J, Britton K (2012) Live plant imports: the major pathway for the forest insect and pathogen invasions of the US. Front Ecol Environ 10:135-143. https://doi.org/10. $1890 / 110198$

Liu HP, Bauer LS, Gao R, Zhao T, Petrice TR, Haack RA (2003) Exploratory survey for the emerald ash borer, Agrilus planipennis (Coleoptera: Buprestidae), and its natural enemies in China. Great Lakes Entomol 36:191-204

Lovett GM, Weiss M, Liebhold AM, Holmes TP, Leung B, Lambert KF, Orwig DA, Campbell FT, Rosenthal J, McCullough DG, Wildova R, Ayres MP, Canham CD, Foster DR, Ladeau SL, Weldy T (2016) Nonnative forest insects and pathogens in the United States: Impacts and policy options. Ecol Appl 26: 1437-1455. https://doi.org/10.1890/15-1176.

Lowe S, Browne M, Boudjelas S, De Poorter M (2000) 100 of the world's Worst Invasive Alien Species. A selection from the Global Invasive Species Database, The Invasive Species Specialist Group, a specialist group of the Species Survival Commission (SSC) of the World Conservation Union (IUCN), p 12

Mansfield S, McNeill MR, Aalders LT, Bell NL, Kean JM, Barratt BIP, Boyd-Wilson K, Teulon DAJ (2019) The value of sentinel plants for risk assessment and surveillance to support biosecurity. NeoBiota 48:1-24. https://doi.org/10.3897/neobiota.48.34205

Maunder M, Culham A, Alden B, Zizka G, Orliac C, Lobin W, Bordeu A, Ramirez JM, Glissmann-Gough S (2000) Conservation of the Toromiro tree: case study in the management of a plant extinct in the wild. Conserv Biol 14:1341-1350. https://doi.org/10.1046/j.1523-1739.2000.98520.x

Mehta SV, Haight RG, Homans FR, Polasky S, Venette RC (2007) Optimal detection and control strategies for invasive species management. Ecol Econ 61:237-245. https://doi.org/10.1016/j.ecolecon.2006.10. 024

Mendel Z, Protosav A, Sharon M, Zveibil A, Ben Yahuda S, O’Donnell K, Rabaglia R, Wysoki M, Freeman S (2012) An Asian ambrosia beetle Euwallacea fornicatus and its novel symbiotic fungus Fusarium sp. pose a serious threat to Israeli avocado industry. Phytoparasitica 40:235-238. https://doi.org/10. 1007/s12600-012-0223-7

Miller A J, Novy A, Glover J, Kellogg EA, Maul JE, Raven P, Jackson PW (2015) Expanding the role of botanical gardens in the future of food. Nat Plant. Article Number 15078. https://doi.org/https://doi. org/10.1038/nplants.2015.78

Morales-Rodríguez C, Anslan S, Auger-Rozenberg M-A, Augustin S, Baranchikov Y, Bellahirech A, Burokienė D, Čepukoit D, Çota E, Davydenko K, Doğmuş Lehtijärvi HT, Drenkhan R, Drenkhan T, Eschen R, Franić I, Glavendekić M, de Groot M, Kacprzyk M, Kenis M, Kirichenko N, Matsiakh I, Musolin DL, Nowakowska JA, O’Hanlon R, Prospero S, Roques A, Santini A, Talgø V, Tedersoo L, Uimari A, Vannini A, Witzell J, Woodward S, Zambounis A, Cleary M (2019) Forewarned is forearmed: harmonized approaches for early detection of potentially invasive pests and pathogens in sentinel plantings. NeoBiota 47:95-123. https://doi.org/10.1016/j.biocontrol.2017.07.009

Oldfield S (2007) Great botanic gardens of the world. New Holland, London

Paap T, Burgess T, Wingfield MJ (2017) Urban trees: bridge-heads for forest pest invasions and sentinels for early detection. Biol Invasions 19:3515-3526. https://doi.org/10.1007/s10530-017-1595-X

Paap T, de Beer ZW, Migliorini D, Nel WJ, Wingfield MJ (2018) The polyphagous shot hole borer (PSHB) and its fungal symbiont Fusarium euwallaceae: a new invasion in South Africa. Australas Plant Path 47:231-237. https://doi.org/10.1007/s13313-018-0545-0

Paap T, Wingfield MJ, Burgess TI, Hulbert JM, Santini A (2020) Harmonising the fields of invasion science and forest pathology. NeoBiota 62:301-3032. https://doi.org/10.1016/j.tree.2004.07.021

Pilkington LJ, Irvin NA, Hoddle MS, Triapitsyn SV, Carey BG, Jones WA, Morgan DJW (2005) Introduced parasitic wasps could control glassy-winged sharpshooter. Calif Agric 59:223-228. https://doi.org/10. 3733/ca.v059n04p223

Pimentel D, Zuniga R, Morrison D (2005) Update on the environmental and economic costs associated with alien-invasive species in the United States. Ecol Econ 52:273-288. https://doi.org/10.1016/j.ecolecon. 2004.10.002 
Pluess T, Jarosik V, Pysek P, Cannon R, Pergl J, Breukers A, Bacher S (2012) Which factors affect the success or failure of eradication campaigns against alien species? PLoS ONE 7(826):e48157. https://doi. org/10.1371/journal.pone.0048157

Powledge F (2011) The evolving role of botanical gardens. Bioscience 61:743-749. https://doi.org/10.1525/ bio.2011.61.10.3

Pratt CF, Constantine KL, Murphy ST (2017) Economic impacts of invasive alien species on African smallholder livelihoods. Glob Food Sec 14:31-37. https://doi.org/10.1016/j.gfs.2017.01.011

Rigling D, Prospero S (2018) Cryphonectria parasitica, the causal agent of chestnut blight: invasion history, population biology and disease control. Mol Plant Pathol 19:7-20. https://doi.org/10.1111/mpp.12542

Rodoni B, Gardner R, Giles R, Cole M, Wimalajeewa S (2002) National surveys did not detect Erwinia amylovora on host plants in Australia. Acta Hortic 590:39-45. https://doi.org/10.17660/ActaHortic. 2002.590 .3

Roques A, Rabitsch W, Rasplus J-Y, Lopez-Vaamonde C, Nentwig W, Kenis M (2009) Alien terrestrial invertebrates of Europe. In: DAISIE, (ed) Handbook of alien species in Europe. Springer, Berlin, pp $63-79$

Roques A, Fan J, Courtial B, Zhang Y, Yart A, Auger-ozenberg M, Denux O, Kenis M, Baker R, Sun J (2015) Planting Sentinel European trees in Eastern Asia as a novel method to identify potential insect pest invaders. PLoS ONE. https://doi.org/10.1371/journal.pone.0120864

Salisbury A, Malumphy C, Halstead AJ (2011) First incursion of Aloea australis (Hemiptera: Miridae) and Pulvinaria delottoi (Hemiptera: Coccidae) in Europe, and three other Hemipteran insects imported from South Africa. Br J Ent Nat Hist 24:217-220

Santini A, Ghelardini L, De Pace C, Desprez-Loustau M-L, Capretti P, Chandelier A, Cech T, Chira D, Diamandis S, Gaitniekis T, Hantula J, Holdenrieder O, Jankovsky L, Jung T, Jurc D, Kirisits T, Kunca A, Lygis V, Malecka M, Marcais B, Schmitz S, Schumacher J, Solheim H, Solla A, Szabo I, Tsopelas P, Vannini A, Vettraino A, Webber J, Woodward S, Stenlid J (2013) Biogeographical patterns and determinants of invasion by forest pathogens in Europe. New Phytol 197:238-250. https://doi.org/10.1111/j. 1469-8137.2012.04364.x

Santini A, Liebhold A, Migliorini D, Woodward S (2018) Tracing the role of human civilization in the globalization of plant pathogens. ISME J 12:647-652. https://doi.org/10.1098/rsos.150370

Scalera R, De Man D, Klausen B, Dickie L, Genovesi P (2012) European code of conduct on zoological gardens and aquaria and invasive alien species. Council of Europe, New edition November 2016

Scott-Brown AS, Hodgetts J, Simmonds MSJ, Collins DW (2018) Potential role of botanic garden collections in predicting hosts at risk globally from invasive pests: a case study using Scirtothrips dorsalis. J Pest Sci 91:60-611. https://doi.org/10.2307/2261425

Sharrock SL, Blackmore S, Cheney J, Dunn C, Husby C, Jebb M, Kennedy K, Kiehn M, Kramer A, Kueffer C, Raven P, Reichard S, Rejmanek M, Oldfield S, Wyse Jackson P (2011) The biodiversity benefits of botanic gardens. Trends Ecol Evol 26:433. https://doi.org/10.1016/j.tree.2011.05.008

Sheridan JE (1989) Quarantine risks imposed by overseas passengers. N Z J For Sci 19(338):346

Smith P (2019) The challenge for botanic garden science. Plants People Planet 1:38-43

Sweeney J, Anderson RS, Webster RP, Nevill R (2012) First records of Orchestes fagi (L.) (Coleoptera: Curculionidae: Curculioninae) in North America, with a checklist of the North American Ramphini. Coleopts Bull 66:297-304. https://doi.org/10.1649/072.066.0401

Tchotet Tchoumi JM, Coetzee MPA, Rajchenberg M, Roux J (2019) Taxonomy and species diversity of Ganoderma species in the Garden Route National Park of South Africa inferred from morphology and multilocus phylogenies. Mycologia 11:730-747. https://doi.org/10.1080/00275514.2019.1635387

Thakur MP, van der Putten WH, Cobben MMP, van Kleunen M, Geisen S (2019) Microbial invasions in terrestrial ecosystems. Nat Rev Microbiol 17:621-631. https://doi.org/10.1038/s41579-019-0236-z

Walter R (2012) Economic relations between Europe and the world: Dependence and Interdependence. European History Online (EGO), published by the Leibniz Institute of European History (IEG). http:// ieg-ego.eu/en/threads/europe-and-the-world/economic-relations. Accessed 21 Aug 2020

Wingfield MJ, Brockerhoff EG, Wingfield BD, Slippers B (2015) Planted forest health: the need for a global strategy. Science 349:832-836. https://doi.org/10.1126/science.aac6674

Wylie FR, Griffiths M, King J (2008) Development of hazard site surveillance programs for forest invasive species: a case study from Brisbane, Australia. Austral For 71:229-235. https://doi.org/10.1080/00049 158.2008.10675040

Publisher's Note Springer Nature remains neutral with regard to jurisdictional claims in published maps and institutional affiliations. 


\section{Authors and Affiliations}

\section{Mesfin Wondafrash ${ }^{1,2}$. Michael J. Wingfield ${ }^{3}$ (D) John R. U. Wilson ${ }^{2,4}$ (D) Brett P. Hurley ${ }^{1}$ (D) . Bernard Slippers ${ }^{3}$ (D) . Trudy Paap ${ }^{3}$ (D)}

1 Department of Zoology and Entomology, Forestry and Agricultural Biotechnology Institute (FABI), University of Pretoria, Pretoria 0002, South Africa

2 South African National Biodiversity Institute, Kirstenbosch Research Centre, Cape Town, South Africa

3 Department of Biochemistry, Genetics and Microbiology, Forestry and Agricultural Biotechnology Institute (FABI), University of Pretoria, Pretoria 0002, South Africa

4 Centre for Invasion Biology, Department of Botany and Zoology, Stellenbosch University, Stellenbosch, South Africa 